\title{
Effects of Physicians' Information Giving on Patient Outcomes: a Systematic Review
}

\author{
Hanne C. Lie, $P h D^{7}$, Lene K. Juvet, $P h D^{2,3}$, Richard L. Street Jr, PhD', \\ Pål Gulbrandsen, $P h D^{5,6}$, Anneli V. Mellblom, PhD ${ }^{1,7}$, Espen Andreas Brembo, PhD², \\ Hilde Eide, PhD², Lena Heyn, PhD², Kristina H. Saltveit ${ }^{7}$, Hilde Strømme, MSC ${ }^{8}$, \\ Vibeke Sundling, $P h D^{2,9}$, Eva Turk, $P h D^{2,10}$, and Julia Menichetti, $P h D^{5,6}$
}

\begin{abstract}
'Department of Behavioral Medicine, Institute of Basic Medical Sciences, Faculty of Medicine, University of Oslo, Oslo, Norway; ${ }^{2}$ Centre for Health and Technology, Faculty of Health and Social Sciences, University of South-Eastern Norway, Drammen, Norway; ${ }^{3}$ Norvegian Institute of Public Health, Oslo, Norway; ${ }^{4}$ Department of Communication, Texas A\&M University, College Station, TX, USA; ${ }^{5}$ Institute of Clinical Medicine, University of Oslo, Oslo, Norway; ${ }^{6}$ Health Services Research $(\mathrm{H} \varnothing \mathrm{KH})$ Centre, Akershus University Hospital, Lørenskog, Norway; ${ }^{7}$ Regional Centre for Child and Adolescent Mental Health, Eastern and Southern Norway (RBUP), Oslo, Norway; ${ }^{2}$ Library of Medicine and Science, University of Oslo, Oslo, Norway; ${ }^{9}$ Department of Optometry, Radiography and Lighting Design, University of South-Eastern Norway, Kongsberg, Norway; ${ }^{10}$ Medical Faculty,

University of Maribor, Maribor, Slovenia.
\end{abstract}

BACKGROUND: Providing diagnostic and treatment information to patients is a core clinical skill, but evidence for the effectiveness of different information-giving strategies is inconsistent. This systematic review aimed to investigate the reported effects of empirically tested communication strategies for providing information on patientrelated outcomes: information recall and (health-related) behaviors.

METHODS: The databases MEDLINE, Embase, PsycINFO (Ovid), Cochrane Central Register of Controlled Trials, and relevant bibliographies were systematically searched from the inception to April 24, 2020, without restrictions, for articles testing information-giving strategies for physicians (PROSPERO ID: CRD42019115791). Pairs of independent reviewers identified randomized controlled studies with a low risk of selection bias as from the Cochrane risk of bias 2 tool. Main outcomes were grouped into patient information recall and behavioral outcomes (e.g., alcohol consumption, weight loss, participation in screening). Due to high heterogeneity in the data on effects of interventions, these outcomes were descriptively reported, together with studies', interventions', and information-giving strategies' characteristics. PRISMA guidelines were followed.

RESULTS: Seventeen of 9423 articles were included. Eight studies, reporting 10 interventions, assessed patient information recall: mostly conducted in experimental settings and testing a single information-giving strategy. Four of the ten interventions reported significant increase in recall. Nine studies assessed behavioral outcomes, mostly in real-life clinical settings and testing multiple information-giving strategies simultaneously. The heterogeneity in this group of studies was high. Eight of the nine interventions reported a significant positive effect on objectively and subjectively measured patients' behavioral outcomes.

Received March 25, 2021

Accepted July 14, 2021

Published online August 5, 2021
DISCUSSION: Using specific framing strategies for achieving specific communication goals when providing information to patients appears to have positive effects on information recall and patient health-related behaviors. The heterogeneity observed in this group of studies testifies the need for a more consistent methodological and conceptual agenda when testing medical informationgiving strategies.

TRIAL REGISTRATION: PROSPERO registration number: CRD42019115791

KEY WORDS: systematic review; medical information; medical communication; behavioral change; information recall.

J Gen Intern Med 37(3):651-63

DOI: $10.1007 / \mathrm{s} 11606-021-07044-5$

(c) The Author(s) 2021

\section{INTRODUCTION}

According to gold standards of high-quality, modern medical care, patients should be informed about and involved in their care. $^{1-3}$ This patient right is mandated by law in many countries. $^{4,5}$ Patient recall and comprehension of medical information are prerequisites for providing informed consent, making informed treatment decisions, lifestyle, and self-management, and adhering to treatment recommendations. ${ }^{6,7}$ However, medical information is often complex and place great demands on both physicians' information giving and knowledge translation skills and the patients' capacity to understand, remember, and ultimately act on the information received. ${ }^{8}$ The process of informing patients involves a dynamic interplay between physicians' skills in presenting information in a clear, relevant, and actionable way, and patients' health literacy skills. ${ }^{3}$ This review focuses on physicians' information exchange practices and associated patient-related behavioral outcomes.

Physicians have a moral and professional obligation to provide high-quality information to patients and secure their 
comprehension. ${ }^{4,9}$ Although physicians often assume that their explanations and instructions are easy to understand, they are often misunderstood by their patients. ${ }^{10,11}$ Patients commonly forget or misunderstand $40-80 \%$ of the information provided by physicians. ${ }^{11-14}$ The personal and societal costs of ineffective information giving are high: non-adherence to treatments ${ }^{15}$, medical errors ${ }^{16}$, longer hospital stays, frequent re-admissions ${ }^{17}$, patient complaints and litigations ${ }^{18}$, poor patient health ${ }^{19,20}$, and healthcare costs. ${ }^{21}$

Effective information giving requires a complex interaction of content, form, and use: speakers formulate what (the content) and choose how to say something to achieve their goal. Most of the medical literature has focused on the content of the information. Evidence that informational content on its own promotes patient outcomes is poor and, if present, most studies have focused on visual or written information in addition to the medical talk. ${ }^{21-23}$ Little attention has been given to how the medical information is provided by physicians during a consultation. Addressing this knowledge gap, we performed an initial scoping review, where we identified a range of strategies for effective information giving for different purposes, i.e., to support patient comprehension, persuade patients, build a relationship, or report facts objectively. ${ }^{24}$ Whether using communication strategies for providing medical information improves patient-related outcomes remains, to the best of our knowledge, unknown. ${ }^{25}$ There is some evidence for an association between general physician communication skills and patient outcomes, but these systematic reviews and/or metaanalyses report on generic communication interventions and show equivocal results. ${ }^{26-30}$ Without evidence for how the information is provided by physicians in the medical talk, it is difficult to identify what features of information-giving are associated with better outcomes and how best to design training programs to optimize the effectiveness of the information exchange.

In this systematic review, we describe the reported effects of physicians' information-giving strategies on patient-related outcomes, as well as the features of these strategies and of the randomized controlled trials (RCTs) testing them.

\section{METHODS}

\section{Protocol}

This systematic review was conducted and reported in accordance with the Preferred Reporting Items for Systematic Review and Meta-analysis (PRISMA) guidelines. ${ }^{31}$ The review protocol is registered in PROSPERO (ID: CRD42019115791).

\section{Eligibility Criteria}

Relevant RCTs were identified through a previously reported scoping review of physicians' information-giving strategies in the dialog with patients. ${ }^{24} \mathrm{RCT}$ studies were eligible for this study if they had a low risk of selection bias assessed with the Risk of Bias 2 (RoB2) tool and if they tested the effect of specified information-giving strategies used by physicians in dialog with patients/analog patients across any medical setting on patient-related outcomes. Studies based on a mix of physicians and other healthcare professionals were included.

Eligible interventions included consultations in which defined strategies for communicating medical information to patients were tested. Eligible comparisons comprised any type of controls.

Outcomes were patient-related, broadly categorized into patient information recall and behavioral outcomes. We excluded outcomes that were assessed in only one eligible study (i.e., satisfaction, quality of life, anxiety, stress, patient's perceived physician competence). We also excluded trust outcomes because of the scientific debate about the conceptual, methodological, and empirical fragility of trust in the medical relationship ${ }^{32}$, especially in relation to physicians' information giving. ${ }^{33}$

\section{Search Strategy and Data Sources}

We searched the databases MEDLINE, Embase, PsycINFO (Ovid), and Cochrane Central Register of Controlled Trials from inception to 24 April 2020 without restrictions. We developed the search strategy with an expert medical librarian (HS). Initial search terms were gathered from a set of key articles, then using an iterative process to develop the final search strategy based on relevant key terms and subject headings (Appendix Table 4). We also screened the reference lists of included or relevant articles to retrieve additional references.

\section{Study Selection}

Screening for inclusion in the initial scoping review was conducted independently by five pairs of reviewers. Conflicts were solved by discussion with a third reviewer. Screening for RCTs to be included in this study was performed by three reviewers (J. M., H. C. L., L. K. J.) based on unequivocal low risk of selection bias from RoB2 assessment, reported previously. ${ }^{24}$

\section{Data Extraction}

Data extraction was performed by pairs of researchers. Data on the reported effects of the included interventions on patientrelated outcomes were extracted using a predefined document. When different data on the same outcome were reported, we selected the information with greater reliability in terms of type of measure. Authors were contacted to retrieve missing or incomplete data.

Specific data were selected and extracted to describe the studies, Table 1. Details about the information-giving strategies were also extracted from studies, reported in Table 2. Unique information-giving strategies were considered to be the modified minimal units of actions concerning information provision. These were extracted word by word ("Specific 
Table 1 Characteristics of Information Provision Interventions Assessing Patient Information Recall and Behavioral Outcomes

\begin{tabular}{|c|c|c|c|c|c|}
\hline Author, year, country & Study design & Clinical task & Physicians' specialty, $n$ & Type of patients, $n$ & $\begin{array}{l}\text { Mean age patients } \\
\text { (SD/range); \% } \\
\text { women }\end{array}$ \\
\hline \multicolumn{6}{|c|}{ Interventions assessing patient information recall } \\
\hline $\begin{array}{l}\text { Ackermann et al. } 2017 \\
\text { (Switzerland) }\end{array}$ & $\mathrm{RCT}$ & $\begin{array}{l}\text { Explaining } \\
\text { clinical issues } \\
\text { |discharge }\end{array}$ & Physicians, NR & Analog patients; 234 & $22(3.6), 70 \%$ \\
\hline $\begin{array}{l}\text { Bennett et al. } 2009 \\
\text { (USA) }\end{array}$ & $\mathrm{RCT}$ & $\begin{array}{l}\text { Clarifying } \\
\text { informed consent } \\
\text { form }\end{array}$ & Radiologists, 8 & $\begin{array}{l}\text { Patients undergoing } \\
\text { spine injections; } 65\end{array}$ & NR, NR \\
\hline $\begin{array}{l}\text { Danzi et al. } 2018 \\
\text { (Italy) }\end{array}$ & $\begin{array}{l}\text { Experimental } \\
\text { video-vignette } \\
\text { study }\end{array}$ & $\begin{array}{l}\text { Explaining } \\
\text { treatment under } \\
\text { emotions }\end{array}$ & Physicians, NR & $\begin{array}{l}\text { Analog patients |healthy } \\
\text { women; } 54\end{array}$ & $25.5(9.2), 100 \%$ \\
\hline $\begin{array}{l}\text { Lehmann et al. 2020a } \\
\text { (The Netherlands) }\end{array}$ & $\begin{array}{l}\text { Experimental } \\
\text { video-vignette } \\
\text { study }\end{array}$ & $\begin{array}{l}\text { Explaining } \\
\text { clinical issues }\end{array}$ & Oncologists, NR & $\begin{array}{l}\text { Analog patients |cancer } \\
\text { patients, survivors, } \\
\text { healthy; } 253\end{array}$ & $61.3(11.7), 54 \%$ \\
\hline $\begin{array}{l}\text { Lehmann et al. 2020b } \\
\text { (The Netherlands) }\end{array}$ & $\begin{array}{l}\text { Experimental } \\
\text { video-vignette } \\
\text { study }\end{array}$ & $\begin{array}{l}\text { Explaining } \\
\text { clinical issues }\end{array}$ & Oncologists, NR & $\begin{array}{l}\text { Analog patients } \mid \text { cancer } \\
\text { patients, survivors, } \\
\text { healthy; } 148\end{array}$ & $61.8(10.1), 50 \%$ \\
\hline $\begin{array}{l}\text { Lehmann et al. 2020b } \\
\text { (The Netherlands) }^{38}\end{array}$ & $\begin{array}{l}\text { Experimental } \\
\text { video-vignette } \\
\text { study }\end{array}$ & $\begin{array}{l}\text { Explaining } \\
\text { clinical issues }\end{array}$ & Oncologists, NR & $\begin{array}{l}\text { Analog patients |cancer } \\
\text { patients, survivors, } \\
\text { healthy; } 148\end{array}$ & $61.8(10.1), 50 \%$ \\
\hline $\begin{array}{l}\text { Visser et al. } 2019 \\
\text { (The Netherlands) }\end{array}$ & $\begin{array}{l}\text { Experimental } \\
\text { video-vignette } \\
\text { study }\end{array}$ & $\begin{array}{l}\text { Explaining } \\
\text { clinical issues }\end{array}$ & Physicians, NR & $\begin{array}{l}\text { Analog patients } \\
\text { students; } 137\end{array}$ & $21(2.7), 86 \%$ \\
\hline $\begin{array}{l}\text { Visser et al. } 2019 \\
\text { (The Netherlands) }\end{array}$ & $\begin{array}{l}\text { Experimental } \\
\text { video-vignette } \\
\text { study }\end{array}$ & $\begin{array}{l}\text { Explaining } \\
\text { clinical issues }\end{array}$ & Physicians, NR & $\begin{array}{l}\text { Analog patients } \\
\text { students; } 136\end{array}$ & $21(2.7), 86 \%$ \\
\hline $\begin{array}{l}\text { Werner et al. } 2013 \\
\text { (Germany) }\end{array}$ & $\mathrm{RCT}$ & $\begin{array}{l}\text { Clarifying } \\
\text { informed consent } \\
\text { form }\end{array}$ & Medical students, 30 & $\begin{array}{l}\text { Analog patients | } \\
\text { medical students; } 30\end{array}$ & $25(4), 57 \%$ \\
\hline $\begin{array}{l}\text { Biglino et al. } 2015 \\
\text { (UK) }\end{array}$ & RCT & $\begin{array}{l}\text { Explaining } \\
\text { clinical issues }\end{array}$ & Cardiologists, NR & $\begin{array}{l}\text { Parents of children with } \\
\text { congenital heart disease; } \\
97\end{array}$ & $\mathrm{NR}, 75 \%$ \\
\hline \multicolumn{6}{|c|}{ Interventions assessing patient behavioral outcomes } \\
\hline $\begin{array}{l}\text { Ockene et al. } 1999 \\
\text { (USA) }^{42}\end{array}$ & $\mathrm{RCT}$ & $\begin{array}{l}\text { Improving health } \\
\text { behaviors }\end{array}$ & $\begin{array}{l}\text { Mixed (physicians, } \\
\text { residents, nurses), } 29\end{array}$ & High risk drinking; 481 & $45(13.4) ; 37 \%$ \\
\hline $\begin{array}{l}\text { Aveyard et al. } 2016 \\
\text { (UK) }\end{array}$ & RCT & $\begin{array}{l}\text { Improving health } \\
\text { behaviors }\end{array}$ & $\begin{array}{l}\text { Primary care physicians, } \\
137\end{array}$ & Obese; 1882 & $56(16.1) ; 57 \%$ \\
\hline $\begin{array}{l}\text { Boguradzka et al. } 2014 \\
\text { (Poland) } 44\end{array}$ & $\mathrm{RCT}$ & $\begin{array}{l}\text { Improving health } \\
\text { behaviors }\end{array}$ & $\begin{array}{l}\text { Primary care physicians, } \\
4\end{array}$ & $\begin{array}{l}\text { Visiting GP for routine } \\
\text { medical consultation; } \\
600\end{array}$ & NR $(50-65) ; 66 \%$ \\
\hline $\begin{array}{l}\text { Grimaldo et al. } 2001 \\
\text { (USA) }\end{array}$ & $\mathrm{RCT}$ & $\begin{array}{l}\text { Planning } \\
\text { advanced care }\end{array}$ & Anesthesiologists, 4 & $\begin{array}{l}\text { Older patients scheduled } \\
\text { for elective surgery; } 195\end{array}$ & $72.8(5.6) ; 40 \%$ \\
\hline $\begin{array}{l}\text { Grover et al. } 2007 \\
\text { (Canada) }\end{array}$ & $\mathrm{RCT}$ & $\begin{array}{l}\text { Improving health } \\
\text { behaviors }\end{array}$ & $\begin{array}{l}\text { Primary care physicians, } \\
230\end{array}$ & $\begin{array}{l}\text { High risk cardio } \\
\text { patients; } 3053\end{array}$ & $56.3(8.1) ; 30 \%$ \\
\hline $\begin{array}{l}\text { Kim et al. } 2019 \\
\text { (Korea) }\end{array}$ & RCT & $\begin{array}{l}\text { Improving health } \\
\text { behaviors }\end{array}$ & Cardiologists, NR & $\begin{array}{l}\text { Smoking patients with } \\
\text { acute coronary } \\
\text { syndrome; } 66\end{array}$ & $55.9(9.0) ; 3 \%$ \\
\hline $\begin{array}{l}\text { Lamb et al. } 1994 \\
\text { (USA) }\end{array}$ & RCT & $\begin{array}{l}\text { Explaining } \\
\text { clinical issues } \\
\text { discharge }\end{array}$ & $\begin{array}{l}\text { Mixed (physicians, } \\
\text { nurses), NR }\end{array}$ & $\begin{array}{l}\text { Patients with new drugs; } \\
203\end{array}$ & 53 (NR); 77\% \\
\hline $\begin{array}{l}\text { Mazza et al. } 2020 \\
\text { (Australia) }\end{array}$ & Cluster RCT & $\begin{array}{l}\text { Explaining } \\
\text { clinical issues }\end{array}$ & GPs, 57 & $\begin{array}{l}\text { Sexually active women; } \\
626\end{array}$ & NR (16-45); 100\% \\
\hline $\begin{array}{l}\text { Saha and Beach } 2011 \\
\text { (USA) }\end{array}$ & $\begin{array}{l}\text { Experimental } \\
\text { video-vignette } \\
\text { study }\end{array}$ & $\begin{array}{l}\text { Improving health } \\
\text { behaviors }\end{array}$ & Cardiologists, NR & $\begin{array}{l}\text { Coronary heart disease } \\
\text { patients; } 248\end{array}$ & 58 (10.9); 59\% \\
\hline
\end{tabular}

message/strategy" in Table 2), organized into strategy types, and strategy types were classified into main categories based on underlying mechanisms of functioning (Table 2, the categorization process is reported elsewhere). ${ }^{24}$

\section{Data Analysis}

As expected, and described in the study protocol, due to the high heterogeneity of studies, interventions, and outcomes (confirmed also by statistical analyses: $\chi^{2}=98.62, p<$ $0.001 ; I^{2}=92 \%$ for studies including a behavioral outcome; $\chi^{2}=11.33, p=0.25 ; I^{2}=21 \%$ for studies including information recall as outcome), a meta-analysis with pooled quantitative summary estimates was deemed inappropriate. Therefore, all effects reported, study by study, were qualitatively synthetized, descriptively summarized without summary estimates in tables, and visualized through forest plots obtained with Review Manager version 5.4.1.

\section{RESULTS}

\section{Overview of Studies}

We initially screened 9423 abstracts and 175 full-text articles of which 39 were included in the initial scoping review. ${ }^{24}$ Of 
Table 2 Information-Giving Intervention, Strategy(ies), Strategy Type(s), and Strategy Category(ies) Targeted by Each Study

\begin{tabular}{|c|c|c|c|c|c|}
\hline Author, year & Intervention & Specific message/strategy & $\begin{array}{l}\text { Strategy type }(N \\
\text { strategies) }\end{array}$ & $\begin{array}{l}\text { Strategy } \\
\text { category }\end{array}$ & Outcome \\
\hline $\begin{array}{l}\text { Ackermann } \\
\text { et al. } 2017^{34}\end{array}$ & $\begin{array}{l}\text { Structuring the presentation of } \\
\text { discharge information }\end{array}$ & $\begin{array}{l}\text { Structured information, following } \\
\text { the structural elements of a book, in } \\
\text { which the content is presented in a } \\
\text { specific order, from high-level in- } \\
\text { formation (e.g., title, table of con- } \\
\text { tents, chapter headings) to detailed, } \\
\text { low-level information }\end{array}$ & Structuring (1) & $\mathrm{C}$ & Immediate recall \\
\hline $\begin{array}{l}\text { Bennett et al. } \\
2009^{35}\end{array}$ & Diagrams added to speech & $\begin{array}{l}\text { Showing a set of diagrams } \\
\text { illustrating the twelve key points } \\
\text { addressed by the informed consent } \\
\text { form before signing it }\end{array}$ & Visualization (1) & $\mathrm{C}$ & Recognition \\
\hline $\begin{array}{l}\text { Danzi et al. } \\
2018^{36}\end{array}$ & $\begin{array}{l}\text { Affective communication } \\
\text { while delivering bad news }\end{array}$ & $\begin{array}{l}\text { Four supportive statements: "But } \\
\text { whatever action we do take, and } \\
\text { however that develops, we will }\end{array}$ & $\begin{array}{l}\text { Emotional- } \\
\text { responsiveness (1) }\end{array}$ & $\mathrm{R}$ & $\begin{array}{l}\text { Active recall } \\
\text { and recognition }\end{array}$ \\
\hline
\end{tabular}

Lehmann

et al. $2020 \mathrm{a}^{37}$

Lehmann

et al. $2020 b^{38}$

Tailoring the amount of preferred information Affect-oriented, caring communication style

Lehmann et al. $2020 b^{38}$

Cognition-oriented communication style with information structuring

$\begin{array}{ll}\text { Visser et al. } & \text { Emotion-oriented } \\ 2019^{39} & \text { communication }\end{array}$

communication

Visser et al. Emotion-oriented

$2019^{39} \quad$ communication

Werner et al. Communication skills training $2013^{40} \quad$ aimed to reduce a layperson's cognitive load

Biglino et al. $2015^{41}$

Ockene et al. $1999^{42}$

Aveyard et al. $2016^{43}$

Brief intervention offering referral to a weight management group however that develops, we will continue to take good care of you.

We will be with you all the way,"

"We will do and will continue to do our very best for you," "And

whatever happens, we will never let you down. You are not facing this on your own," "I completely understand your reluctance. We'll look at this decision together carefully and we'll pay attention to your concerns."

Amount of information tailored to patients' preferences

Utterances that validate the patient's emotional burden and convey understanding (e.g., I can imagine that you're worried; I understand that this is a tough and uncertain period for you)

Four signs of structuring: verbal signals that introduce a certain topic/ agenda, that introduce a summary, that use numeric signals (e.g., first, ...second...), and visual signs such as finger/hand signals when counting/using numeric signals Emotion-oriented silence (passive style): listen attentively until the patient resumes the conversation

Emotion-oriented speech (active style): acknowledging and/or exploring the patient's emotional expressions, providing empathic and supportive statements

Assessing what the patient already

knows, using easy and understandable language adapted to the patient's level, active encouragement to ask questions, making use of the available information sheets for medical procedures, reducing the amount of information by clustering the facts (e.g., combining each operative step with its possible complication)

Providing a three-dimensional model of the cardiac lesion(s) and discuss it during the appointment

Use of nondirective, open-ended questions (e.g., "How do you feel about drinking?" or "How might you go about cutting down?"); the providers were also taught to use patient education materials (i.e., tip sheets) and a goal statement.

Offer of help/referral to change

behaviors; ask patients to return
Quantity (1)

Emotional

responsiveness (1)

C

$\mathrm{R}$

Structuring (1)

C

$\mathrm{R}$

responsiveness

(emotion-oriented

silence) (1)

Emotional

responsiveness

(emotion-oriented

speech) (1)

Simplification, structuring, teach-

back, visualization (4)

Visualization (1)

C

Change in

Open-ended questions, C visualization (2)

$\mathrm{R}$

Active recall

Active recall and recognition

Active recall and recognition

Active recall and recognition knowledge

Alcohol consumption

Directivity (1)

P

Weight change 
Table 2. (continued)

\begin{tabular}{|c|c|c|c|c|c|}
\hline Author, year & Intervention & Specific message/strategy & $\begin{array}{l}\text { Strategy type }(N \\
\text { strategies) }\end{array}$ & $\begin{array}{l}\text { Strategy } \\
\text { category }\end{array}$ & Outcome \\
\hline $\begin{array}{l}\text { Boguradzka } \\
\text { et al. } 2014{ }^{44}\end{array}$ & $\begin{array}{l}\text { Physicians' counseling on } \\
\text { colonoscopy screening }\end{array}$ & $\begin{array}{l}\text { Standardized discussion with basic } \\
\text { information on the disease, rationale } \\
\text { for screening and benefits of early } \\
\text { treatment and prevention, } \\
\text { recommendation to participate in } \\
\text { screening, information on screening } \\
\text { procedure }\end{array}$ & $\begin{array}{l}\text { Standardization, } \\
\text { argumentation (2) }\end{array}$ & $\mathrm{P}+\mathrm{O}$ & $\begin{array}{l}\text { Participation in } \\
\text { screening }\end{array}$ \\
\hline $\begin{array}{l}\text { Grimaldo } \\
\text { et al. } 2001^{45}\end{array}$ & $\begin{array}{l}\text { Short information session } \\
\text { stressing the importance of } \\
\text { patients-proxies' } \\
\text { communication about end-of- } \\
\text { life care }\end{array}$ & $\begin{array}{l}\text { Guidelines-driven information; } \\
\text { provision of examples regarding } \\
\text { cardiopulmonary resuscitation and } \\
\text { mechanical ventilation; } \\
\text { encouragement to talk with the } \\
\text { proxies about end of life wishes }\end{array}$ & $\begin{array}{l}\text { Standardization, } \\
\text { accuracy, directivity } \\
\text { (3) }\end{array}$ & $\mathrm{P}+\mathrm{O}$ & $\begin{array}{l}\text { Written durable } \\
\text { power of } \\
\text { attorney }\end{array}$ \\
\hline $\begin{array}{l}\text { Grover et al. } \\
2007^{46}\end{array}$ & $\begin{array}{l}\text { Sharing information on future } \\
\text { risks for cardiovascular events }\end{array}$ & $\begin{array}{l}\text { Computer printout that displays a } \\
\text { patient's probability of developing } \\
\text { coronary disease graphically } \\
\text { summarized; ongoing info/feedback }\end{array}$ & $\begin{array}{l}\text { Visualization, } \\
\text { repetition (2) }\end{array}$ & $\mathrm{C}$ & $\begin{array}{l}\text { Blood lipid } \\
\text { levels }\end{array}$ \\
\hline $\begin{array}{l}\text { Kim et al. } \\
2019^{47}\end{array}$ & Aversive advice & $\begin{array}{l}\text { Three sentences on consequences of } \\
\text { dysfunctional behaviors and stress of } \\
\text { losses: "Smoking caused your chest } \\
\text { pain"; "If you do not stop smoking } \\
\text { right now, this pain will come } \\
\text { again"; "The next time you feel this } \\
\text { pain you will probably die." }\end{array}$ & Negative framing (1) & $\mathrm{P}$ & $\begin{array}{l}\text { Smoking } \\
\text { cessation }\end{array}$ \\
\hline $\begin{array}{l}\text { Lamb et al. } \\
1994^{48}\end{array}$ & $\begin{array}{l}\text { Providing patients with } \\
\text { information about potential } \\
\text { side effects }\end{array}$ & $\begin{array}{l}\text { Description of potential side effects } \\
\text { for new medications, in addition to } \\
\text { drug name, purpose, dose }\end{array}$ & Argumentation (1) & $\mathrm{P}$ & $\begin{array}{l}\text { Medication side } \\
\text { effects }\end{array}$ \\
\hline $\begin{array}{l}\text { Mazza et al. } \\
2020^{49}\end{array}$ & $\begin{array}{l}\text { Complex intervention } \\
\text { providing structured } \\
\text { effectiveness-based contracep- } \\
\text { tive counseling and access to } \\
\text { rapid referral }\end{array}$ & $\begin{array}{l}\text { Structured counseling with } \\
\text { nonbiased, scripted descriptions of } \\
\text { all contraceptives with emphasis on } \\
\text { safety and efficacy; recommended } \\
\text { return appointment and rapid referral } \\
\text { pathway to clinic }\end{array}$ & $\begin{array}{l}\text { Structuring, accuracy, } \\
\text { standardization, } \\
\text { directivity (4) }\end{array}$ & $\mathrm{C}+\mathrm{O}+\mathrm{P}$ & $\begin{array}{l}\text { Use of } \\
\text { contraceptive }\end{array}$ \\
\hline $\begin{array}{l}\text { Saha and } \\
\text { Beach } 2011^{51}\end{array}$ & $\begin{array}{l}\text { Patient-centered } \\
\text { communication behaviors }\end{array}$ & $\begin{array}{l}\text { Presence of empathic statements, } \\
\text { presence of elicitation and validation } \\
\text { of patient concerns, more } \\
\text { exploration of patient context and } \\
\text { individualization of discussion, more } \\
\text { rapport building and partnership } \\
\text { statements, more patient education, } \\
\text { use of lay language, nonverbal } \\
\text { behaviors reinforcing verbal } \\
\text { behaviors (positive affect showed } \\
\text { with voice tone and facial } \\
\text { expressions, high attentiveness and } \\
\text { presence conveyed through eye } \\
\text { contact, nodding, and leaning } \\
\text { forward) }\end{array}$ & $\begin{array}{l}\text { Visualization, } \\
\text { personalization, } \\
\text { emotional } \\
\text { responsiveness (3) }\end{array}$ & $\mathrm{C}+\mathrm{R}$ & $\begin{array}{l}\text { Likelihood of } \\
\text { undergoing } \\
\text { treatment }\end{array}$ \\
\hline
\end{tabular}

$C$ cognitive aid strategy (where the strategy had the function of aiding understanding), $O$ objectivity-oriented strategy (where the strategy had the function of objectively reporting information), R relationship-oriented strategy (where the strategy had the function of building the relationship with the patient), P persuasive strategy (where the strategy had the function of persuading the patient to do something)

these, 17 studies were RCTs with low risk of selection bias and eligible for the systematic review (Fig. 1). Two articles tested two different interventions with different participants each $^{38,39}$, and one of these used one common control group. ${ }^{39}$

Trials were published between 1994 and 2020, and included 8256 patients or analog patients. The average age of patients in the 17 studies was 48 years $(S D=17.13)$. Effects of studies are reported separately for the two main outcomes: information recall and behavioral outcomes.

\section{Information Recall Studies}

The effect of information-giving interventions on recall or knowledge outcomes was investigated in eight of the 17 articles, reporting 10 different interventions. Information recall was most frequently assessed as a combination of free recall and recognition. All recall measures were self-reported and assessed immediately after the intervention. One study assessed self-reported parental knowledge/understanding of the child's condition before and after the intervention. ${ }^{41}$

Characteristics of Studies Assessing Information Recall. The number of patients involved in these studies ranged from $30^{40}$ to $253^{37}$ (Table 1). Explaining clinical issues ( 7 of 10 studies) was the most frequent information provision task. In eight of the 10 interventions, participants were analog patients. Former patients were used in three experimental interventions reported in two articles. ${ }^{37,38}$ Six interventions, reported in four articles, were tested in a fictional experimental setting using videovignettes $^{36-39}$, while the others were conducted in real life. 


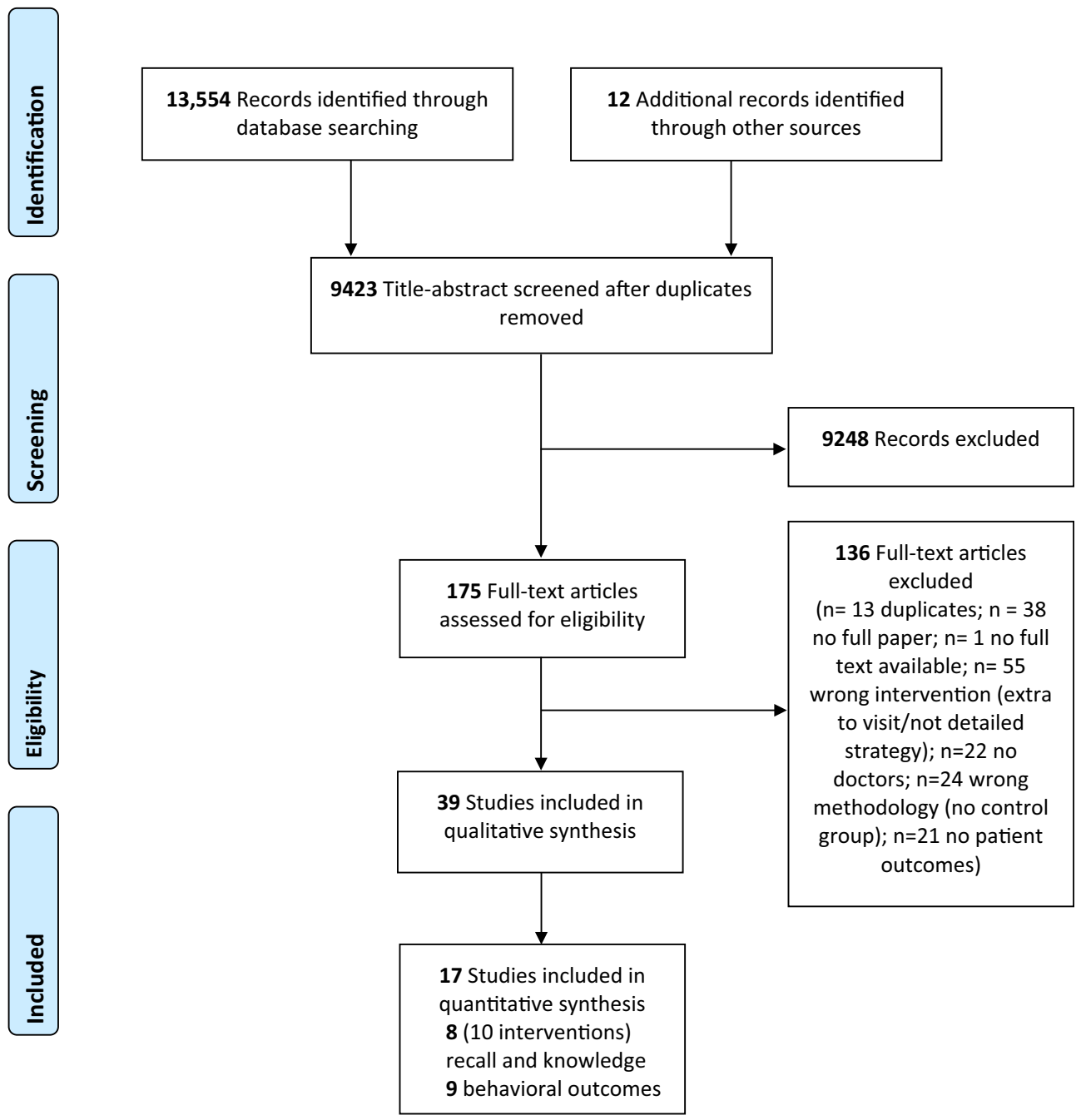

Figure 1 PRISMA Flow chart.

All the 10 interventions tested unique groups of strategies, six studies tested cognitive aid strategies, and four relationship-oriented strategies (Table 2). Nine out of 10 studies also tested one single strategy. Overall, the most frequently tested strategies were emotional responsiveness during information-giving dialogs $\mathrm{s}^{36,38,39}$, information structuring $^{34,38,40}$, and use of visual demonstrations during oral information giving. ${ }^{34,35,41}$

Effects of Interventions on Information Recall. Seven out of 10 interventions showed a positive effect on information recall, with two studies reporting significant changes ${ }^{34,35}$ and two interventions included in one study reporting significant changes in recognition but not in free recall ${ }^{39}$ (Table 3 and Fig. 2). Ackermann et al. ${ }^{34}$ evaluated the effect of structuring (e.g., akin to a book where high-level information is presented as "title and chapter headings" to low-level information as the text) versus non-structuring of the information given at discharge on the amount of information freely recalled by students (acting as analog patients) with different levels of prior medical knowledge. All 234 participants assigned to the structured discharge consultation significantly increased the number of items recalled (17\% increase of recall performance) compared to those receiving non-structured information. The effect was particularly pronounced among those with the least prior medical knowledge (42\% increase of recall performance). Bennet et al. ${ }^{35}$ tested a visual method utilizing diagrams to illustrate key points included in the informed consent form on a small sample of 32 patients compared to two control conditions, usual care and "teach-theteacher" condition where patients are asked to repeat the key points of the informed consent. They found that this visualization strategy significantly increased the number of items recognized by patients compared to the usual care condition, without increasing the average time needed. They did not detect differences between the visualization strategy and the teach-the-teacher strategy, but the latter required more time. Visser et al. ${ }^{39}$ recently compared the effects of oncologists' emotion-oriented speech and emotion-oriented silence during extensive informationgiving sequences on free recall and recognition, compared to giving limited space for emotional disclosure. Both these strategies enhanced recognition but not free recall, with no apparent influence on patient emotional stress level. 
Table 3 Summary of Results for Intervention and Control Conditions for Each Study

\begin{tabular}{|c|c|c|c|c|c|c|c|c|}
\hline $\begin{array}{l}\text { Author, } \\
\text { year }\end{array}$ & $\begin{array}{l}\text { Outcome measure } \\
\text { (details, range); } \\
\text { timing assessment }\end{array}$ & Strategy type & $\begin{array}{l}\text { Type of } \\
\text { control }\end{array}$ & $N(\mathrm{I})$ & $\begin{array}{l}N \\
(\mathrm{C})\end{array}$ & Outcome (I) & Outcome (C) & $\begin{array}{l}\text { Main } \\
\text { effect }\end{array}$ \\
\hline $\begin{array}{l}\text { Ackermann } \\
\text { et al. } 2017^{34}\end{array}$ & $\begin{array}{l}\text { Immediate recall ( } n \\
\text { items recalled, } 0- \\
28) ; \text { just after }\end{array}$ & Structuring & No structuring & 136 & 98 & $\begin{array}{l}\text { Recalled a mean } \\
\text { of } 9.7 \text { items } \\
(35 \%)(\text { range }= \\
0-23)(\mathrm{SD}= \\
4.96)\end{array}$ & $\begin{array}{l}\text { Recalled a mean } \\
\text { of } 8.31 \text { items } \\
(30 \%)(\text { range }= \\
0-19)(\mathrm{SD}= \\
4.93)\end{array}$ & + \\
\hline $\begin{array}{l}\text { Bennett et al. } \\
2009^{35}\end{array}$ & $\begin{array}{l}\text { Recognition } \\
\text { (multiple choice } \\
\text { questionnaire, 0- } \\
\text { 12); just after }\end{array}$ & Visualization & Usual care & 32 & 33 & $\begin{array}{l}\text { mean } 7.3 \pm \mathrm{SD} \\
2.2 \text { (range } 1- \\
10)\end{array}$ & $\begin{array}{l}\text { mean } 5.5 \pm \mathrm{SD} \\
2.5 \text { (range } 0- \\
10)\end{array}$ & + \\
\hline $\begin{array}{l}\text { Danzi et al. } \\
2018^{36}\end{array}$ & $\begin{array}{l}\text { Active recall and } \\
\text { recognition ( } 8 \\
\text { open-ended, } \\
8 \text { completion, and } \\
8 \text { multiple-choice } \\
\text { questions; } 0-48) ; \\
\text { just after }\end{array}$ & $\begin{array}{l}\text { Emotional } \\
\text { responsiveness }\end{array}$ & $\begin{array}{l}\text { Same contents, } \\
\text { no supportive } \\
\text { statements }\end{array}$ & 27 & 27 & $\begin{array}{l}\text { mean } 28.9 \\
( \pm 5.6)[\text { range } \\
17-38]\end{array}$ & $\begin{array}{l}\text { mean } 29.7( \pm \\
7.0)[\text { range } 10- \\
40]\end{array}$ & - \\
\hline $\begin{array}{l}\text { Lehmann } \\
\text { et al. } 2020 a^{37}\end{array}$ & $\begin{array}{l}\text { Active recall and } \\
\text { recognition ( } 14 \\
\text { open-ended and } 14 \\
\text { same multiple- } \\
\text { choice questions; } \\
0-27 \text { each); just af- } \\
\text { ter }\end{array}$ & Quantity & Usual care & 132 & 121 & $\begin{array}{l}\text { For open recall } \\
\text { mean } 55.9(\mathrm{SD} \\
17.5) \text {; for } \\
\text { recognition } \\
\text { mean } 89.6(\mathrm{SD} \\
10.1)\end{array}$ & $\begin{array}{l}\text { For open recall } \\
\text { mean } 54.9(\mathrm{SD} \\
14.6) \text {; for } \\
\text { recognition } \\
\text { mean } 88.4(\mathrm{SD} \\
10.1)\end{array}$ & - \\
\hline $\begin{array}{l}\text { Lehmann } \\
\text { et al. } \\
2020 b^{38}\end{array}$ & $\begin{array}{l}\text { Active recall and } \\
\text { recognition ( } 14 \\
\text { open-ended and } 14 \\
\text { same multiple- } \\
\text { choice questions; } \\
0-27 \text { each); just af- } \\
\text { ter }\end{array}$ & $\begin{array}{l}\text { Emotional } \\
\text { responsiveness }\end{array}$ & Usual care & 70 & 78 & $\begin{array}{l}\text { Open recall } \\
\text { mean } 14.57(\mathrm{SD} \\
4.06) ; \\
\text { recognition } \\
\text { mean } 12.21(\mathrm{SD} \\
1.56)\end{array}$ & $\begin{array}{l}\text { Open recall } \\
\text { mean } 15.94(\mathrm{SD} \\
4.3) ; \text { recognition } \\
\text { mean } 12.32(\mathrm{SD} \\
1.42)\end{array}$ & - \\
\hline $\begin{array}{l}\text { Lehmann } \\
\text { et al. } \\
2020 b^{38}\end{array}$ & $\begin{array}{l}\text { Active recall and } \\
\text { recognition ( } 14 \\
\text { open-ended and } 14 \\
\text { same multiple- } \\
\text { choice questions; } \\
0-27 \text { each); just af- } \\
\text { ter }\end{array}$ & Structuring & Usual care & 74 & 74 & $\begin{array}{l}\text { Open recall } \\
\text { mean } 15.71(\mathrm{SD} \\
4.1) ; \text { recognition } \\
\text { mean } 12.28(\mathrm{SD} \\
1.57)\end{array}$ & $\begin{array}{l}\text { Open recall } \\
\text { mean } \\
14.87(\mathrm{SD} 4.4) ; \\
\text { recognition } \\
\text { mean } 12.26(\mathrm{SD} \\
1.4)\end{array}$ & - \\
\hline $\begin{array}{l}\text { Visser et al. } \\
2019^{39}\end{array}$ & $\begin{array}{l}\text { Active recall and } \\
\text { recognition ( } 8 \\
\text { open-ended and } \\
8 \text { same multiple- } \\
\text { choice questions; } \\
0-24 \text { each); just af- } \\
\text { ter }\end{array}$ & $\begin{array}{l}\text { Emotional } \\
\text { responsiveness, } \\
\text { passive/emotion- } \\
\text { oriented silence }\end{array}$ & Usual care & 68 & 69 & $\begin{array}{l}\text { Mean active } \\
\text { recall } 54.73 \text { (SD } \\
17.2) \text {; mean } \\
\text { recognition } \\
79.96 \text { (SD } \\
17.02)\end{array}$ & $\begin{array}{l}\text { Mean active } \\
\text { recall } 51.9(\mathrm{SD} \\
16.5) \text {; mean } \\
\text { recognition } \\
71.37 \text { (SD } \\
15.91)\end{array}$ & $\begin{array}{l}\text { - for active } \\
\text { recall } \\
+ \text { for } \\
\text { recognition }\end{array}$ \\
\hline $\begin{array}{l}\text { Visser et al. } \\
2019^{39}\end{array}$ & $\begin{array}{l}\text { Active recall and } \\
\text { recognition ( } 8 \\
\text { open-ended and } \\
8 \text { same multiple- } \\
\text { choice questions; } \\
0-24 \text { each); just af- } \\
\text { ter }\end{array}$ & $\begin{array}{l}\text { Emotional } \\
\text { responsiveness, } \\
\text { active/emotion- } \\
\text { oriented speech }\end{array}$ & Usual care & 67 & 69 & $\begin{array}{l}\text { Mean active } \\
\text { recall } 54.52(\mathrm{SD} \\
15.16) ; \text { mean } \\
\text { recognition } \\
77.98(\mathrm{SD} 15.7)\end{array}$ & $\begin{array}{l}\text { Mean active } \\
\text { recall } 51.9 \text { (SD } \\
16.5) \text {; mean } \\
\text { recognition } \\
71.37 \text { (SD } \\
15.91)\end{array}$ & $\begin{array}{l}\text { - for active } \\
\text { recall } \\
+ \text { for } \\
\text { recognition }\end{array}$ \\
\hline $\begin{array}{l}\text { Werner et al. } \\
2013^{40}\end{array}$ & $\begin{array}{l}\text { Active recall (n } \\
\text { items freely } \\
\text { recalled and } \\
\text { recorded on a } \\
\text { blank sheet of } \\
\text { paper); just after }\end{array}$ & $\begin{array}{l}\text { Simplification, } \\
\text { structuring, teach- } \\
\text { back, visualization }\end{array}$ & No training & 15 & 15 & $\begin{array}{l}\text { Mean } 41 \text { (SD } \\
9 \%) \text { after }\end{array}$ & $\begin{array}{l}\text { Mean } 42 \pm 9 \% \\
\text { after }\end{array}$ & - \\
\hline $\begin{array}{l}\text { Biglino et al. } \\
2015^{41}\end{array}$ & $\begin{array}{l}\text { Change in } \\
\text { knowledge (self- } \\
\text { report } \\
\text { questionnaire, 1- } \\
\text { 10); just after }\end{array}$ & Visualization & $\begin{array}{l}\text { No visual } \\
\text { model used } \\
\text { during the visit }\end{array}$ & 45 & 52 & $\begin{array}{l}\text { Before } 7.9 \pm 1.6 \\
\text { and after } 9.1 \\
\pm 1.1\end{array}$ & $\begin{array}{l}\text { Before mean } \\
8.1 \pm \mathrm{SD} 1.7 \text { and } \\
\text { after } 9.0 \pm 1.2\end{array}$ & - \\
\hline $\begin{array}{l}\text { Ockene et al. } \\
1999^{42}\end{array}$ & $\begin{array}{l}\text { Alcohol } \\
\text { consumption (6- } \\
\text { month value minus } \\
\text { baseline); } 6 \text { months }\end{array}$ & $\begin{array}{l}\text { Open-ended } \\
\text { questions, } \\
\text { visualization }\end{array}$ & Usual care & 248 & 233 & $\begin{array}{l}\mathrm{MD}=-6.0 \pm \\
\mathrm{SD} 11.2\end{array}$ & $\begin{array}{l}\mathrm{MD}=-3.1 \pm \\
\mathrm{SD} 10.2\end{array}$ & + \\
\hline $\begin{array}{l}\text { Aveyard } \\
\text { et al. } 2016^{43}\end{array}$ & $\begin{array}{l}\text { Weight change ( } \% \\
\text { who lost }>5 \% \text { of } \\
\text { weight after } 12 \\
\text { months }+ \text { weight } \\
\text { change } 0-12\end{array}$ & Directivity & $\begin{array}{l}\text { Advice to } \\
\text { change } \\
\text { behavior to } \\
\text { benefit health }\end{array}$ & 940 & 942 & $\begin{array}{l}238(25 \%) \text { lost } \\
\text { at least } 5 \% \text { of } \\
\text { bodyweight; } \\
\text { weight change = } \\
-2.43 \mathrm{~kg}\end{array}$ & $\begin{array}{l}131(14 \%) \text { lost } \\
\text { at least } 5 \% \text { of } \\
\text { bodyweight; } \\
\text { weight change = } \\
-1.04 \mathrm{~kg}\end{array}$ & + \\
\hline
\end{tabular}


Table 3. (continued)

\begin{tabular}{|c|c|c|c|c|c|c|c|c|}
\hline $\begin{array}{l}\text { Author, } \\
\text { year }\end{array}$ & $\begin{array}{l}\text { Outcome measure } \\
\text { (details, range); } \\
\text { timing assessment }\end{array}$ & Strategy type & $\begin{array}{l}\text { Type of } \\
\text { control }\end{array}$ & $N(\mathrm{I})$ & $\begin{array}{l}N \\
(\mathrm{C})\end{array}$ & Outcome (I) & Outcome (C) & $\begin{array}{l}\text { Main } \\
\text { effect }\end{array}$ \\
\hline & $\begin{array}{l}\text { months; } 12 \\
\text { months) }\end{array}$ & & & & & & & \\
\hline $\begin{array}{l}\text { Boguradzka } \\
\text { et al. } 2014^{44}\end{array}$ & $\begin{array}{l}\text { Participation in } \\
\text { screening; } 6 \\
\text { months }\end{array}$ & $\begin{array}{l}\text { Standardization, } \\
\text { argumentation }\end{array}$ & $\begin{array}{l}\text { Informational } \\
\text { leaflet }\end{array}$ & 300 & 300 & $\begin{array}{l}141(47 \%) \\
\text { screened }\end{array}$ & $\begin{array}{l}41(13.7 \%) \\
\text { screened }\end{array}$ & + \\
\hline $\begin{array}{l}\text { Grimaldo } \\
\text { et al. } 2001^{45}\end{array}$ & $\begin{array}{l}\text { Written durable } \\
\text { power of attorney } \\
\text { completion rates; } \\
\text { just after }\end{array}$ & $\begin{array}{l}\text { Standardization, } \\
\text { accuracy, } \\
\text { directivity }\end{array}$ & Usual care & 97 & 98 & $\begin{array}{l}16(16 \%) \\
\text { additional } \\
\text { patients wrote } \\
\text { durable power } \\
\text { of attorneys }\end{array}$ & $\begin{array}{l}2(2 \%) \\
\text { additional } \\
\text { patients wrote } \\
\text { durable power } \\
\text { of attorneys }\end{array}$ & + \\
\hline $\begin{array}{l}\text { Grover et al. } \\
2007^{46}\end{array}$ & $\begin{array}{l}\text { Changes in blood } \\
\text { lipid levels and the } \\
\text { frequency of } \\
\text { reaching lipid } \\
\text { targets; } 12 \text { months }\end{array}$ & $\begin{array}{l}\text { Visualization, } \\
\text { repetition }\end{array}$ & Usual care & 1510 & 1543 & $\begin{array}{l}835(55.2 \%) \\
\text { reach lipid } \\
\text { targets }\end{array}$ & $\begin{array}{l}805(52.2 \%) \\
\text { reach lipid } \\
\text { targets }\end{array}$ & - \\
\hline $\begin{array}{l}\text { Kim et al. } \\
2019^{47}\end{array}$ & $\begin{array}{l}\text { Smoking cessation } \\
\text { rates; } 6 \text { months }\end{array}$ & Negative framing & Usual care & 33 & 33 & $\begin{array}{l}22(66.7 \%) \text { quit } \\
\text { smoking at } 6 \\
\text { months }\end{array}$ & $\begin{array}{l}10(30.3 \%) \text { quit } \\
\text { smoking at } 6 \\
\text { months }\end{array}$ & + \\
\hline $\begin{array}{l}\text { Lamb et al. } \\
1994^{48}\end{array}$ & $\begin{array}{l}\text { Patient-reported } \\
\text { incidence of side } \\
\text { effects for } \\
\text { medication; 2-3 } \\
\text { weeks }\end{array}$ & Argumentation & Usual care & 104 & 99 & $\begin{array}{l}40(38 \%) \\
\text { reported side } \\
\text { effects }\end{array}$ & $\begin{array}{l}37(37 \%) \\
\text { reported side } \\
\text { effects }\end{array}$ & - \\
\hline $\begin{array}{l}\text { Mazza et al. } \\
2020^{49}\end{array}$ & $\begin{array}{l}\text { Use of } \\
\text { contraceptive; } 2 \\
\text { months }\end{array}$ & $\begin{array}{l}\text { Structuring, } \\
\text { accuracy, } \\
\text { standardization, } \\
\text { directivity }\end{array}$ & Usual care & 248 & 378 & $\begin{array}{l}48(19.3 \%) \text { with } \\
\text { long-acting re- } \\
\text { versible contra- } \\
\text { ceptive }\end{array}$ & $\begin{array}{l}45(12.9 \%) \text { with } \\
\text { long-acting re- } \\
\text { versible contra- } \\
\text { ceptive }\end{array}$ & + \\
\hline $\begin{array}{l}\text { Saha and } \\
\text { Beach } 2011\end{array}$ & $\begin{array}{l}\text { Self-reported } \\
\text { likelihood of } \\
\text { undergoing } \\
\text { treatment (4-point } \\
\text { scales from } \\
\text { definitely to not at } \\
\text { all); just after }\end{array}$ & $\begin{array}{l}\text { Visualization, } \\
\text { personalization, } \\
\text { emotional } \\
\text { responsiveness }\end{array}$ & $\begin{array}{l}\text { Low patient- } \\
\text { centeredness }\end{array}$ & 134 & 114 & $\begin{array}{l}129(96 \%) \text { said } \\
\text { they would be } \\
\text { more likely to } \\
\text { undergo } \\
\text { treatment }\end{array}$ & $\begin{array}{l}84(74 \%) \text { said } \\
\text { they would be } \\
\text { more likely to } \\
\text { undergo } \\
\text { treatment }\end{array}$ & + \\
\hline
\end{tabular}

I intervention, C control, MD mean difference, SD standard deviation, OD odds ratio; $+=$ significant effect $(<.05) ;-=$ no significant effect $(>.05)$

None of the other interventions reported a statistically significant improvement in information recall. Notably, the most recent study by Lehmann et al. with one of the largest samples in this group of articles $(N=148)^{38}$ tested two of the strategies found to have a positive significant effect in other studies (emotionalresponsiveness and information structuring) but reported no improvements in recall. They found that trust may play a conflicting role in recall because enhanced trust decreased recall, and that patients' personal characteristics (age, gender, education, health literacy) confounded recall outcomes.

\section{Behavioral Outcomes Studies}

Behavioral outcome measures were included in nine of the 17 studies. Behavioral outcomes were assessed objectively in seven and by self-report measures in two studies ${ }^{48,51}$ and included alcohol consumption ${ }^{42}$, weight loss ${ }^{43}$, blood lipid levels ${ }^{46}$, smoking cessation ${ }^{47}$, and treatment-related changes like medication side effects ${ }^{48}$, use of a treatment ${ }^{49}$, or likelihood of undergoing a treatment $^{51}$, participation in screening ${ }^{44}$, and written durable power of attorney. ${ }^{45}$

Characteristics of Studies Assessing Behavioral Outcomes. The number of patients involved in the nine studies assessing behavioral outcomes ranged from $66^{47}$ to $3053^{46}$ (Table 1). Most studies ( 8 of 9 ) were conducted in real-life settings, and one used video-vignettes. ${ }^{51}$ The most frequent clinical task performed was improving health-related behaviors (6 of 9).

In general, each intervention tested multiple information provision strategies (Table 2). The most frequently included strategies were persuasive ( 5 of 9 ) and cognitive aid strategies (4 of 9). Two interventions included cognitive aid strategies combined with objectivity-oriented ${ }^{49}$ or relationship-oriented strategies ${ }^{51}$; two interventions included persuasive strategies combined with objectivity-oriented strategies. $^{44,45}$

Effect of Interventions on Behavioral Outcomes. Eight of the nine studies reported significant improvements in behavioral outcomes (Table 3 and Fig. 3). All the interventions that included a strategy aimed at persuading patients and influencing their thinking and behavior, by being directive $e^{43,45,49}$, providing argumentations ${ }^{44,48}$, or negatively framing the message, reported positive significant improvements on patients' behaviors. Aveyard et al. ${ }^{43}$, Grimaldo et al. ${ }^{45}$, and Mazza et al. ${ }^{49}$ all tested the effect of a direct recommendation from the doctor to engage in extra-visit activities and of planning a follow-up. These strategies were provided alone $\mathrm{e}^{43}$ or in combination with other informationgiving strategies ${ }^{45,49}$, and led patients to reduce their weight ${ }^{43}$, to write a durable power of attorney after 12 months $^{45}$, or to use contraceptives after 2 months ${ }^{49}$. Both Lamb et al. ${ }^{48}$ and 


\begin{tabular}{|c|c|c|c|c|c|c|c|c|c|}
\hline \multirow[b]{2}{*}{ Study or Subgroup } & \multicolumn{3}{|c|}{ Experimental } & \multicolumn{3}{|c|}{ Control } & \multirow{2}{*}{$\begin{array}{l}\text { Std. Mean Difference } \\
\text { IV, Random, } 95 \% \mathrm{Cl}\end{array}$} & \multirow{2}{*}{$\begin{array}{c}\text { Std. Mean Difference } \\
\text { IV, Random, 95\% Cl }\end{array}$} & Risk of Bias \\
\hline & Mean & SD & Total & Mean & SD & Total & & & A B C D E F G \\
\hline Ackermann 2017 & 9.7 & 4.96 & 136 & 8.31 & 4.93 & 98 & $0.28[0.02,0.54]$ & + & $\oplus+? ?+\oplus \uparrow$ \\
\hline Bennett 2009 & 7.3 & 2.2 & 32 & 5.5 & 2.5 & 33 & $0.75[0.25,1.26]$ & & \\
\hline Biglino 2015 & 9.1 & 1.1 & 45 & 9 & 1.2 & 52 & $0.09[-0.31,0.49]$ & - & \\
\hline Danzi 2018 & 28.9 & 5.6 & 27 & 29.7 & 7 & 27 & $-0.12[-0.66,0.41]$ & & \\
\hline Lehmann $2020 a$ & 72.8 & 13.8 & 132 & 71.7 & 12.4 & 121 & $0.08[-0.16,0.33]$ & 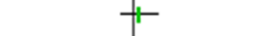 & \\
\hline Lehmann 2020b1 & 13.93 & 2.81 & 70 & 14.13 & 2.86 & 78 & $-0.07[-0.39,0.25]$ & - & \\
\hline Lehmann $2020 \mathrm{~b} 2$ & 13.99 & 2.83 & 73 & 13.56 & 2.9 & 74 & $0.15[-0.17,0.47]$ & + & \\
\hline Visser $2019 a$ & 67.35 & 17.11 & 68 & 61.64 & 16.2 & 35 & $0.34[-0.07,0.75]$ & + & †? ? ? $\odot$ \\
\hline Visser $2019 \mathrm{~b}$ & 66.25 & 15.43 & 67 & 61.64 & 16.2 & 34 & $0.29[-0.12,0.71]$ & + & \\
\hline \multirow[t]{2}{*}{ Werner 2013} & 41 & 9 & 15 & 42 & 9 & 15 & $-0.11[-0.82,0.61]$ & & 72 \\
\hline & & & & & & & & $\begin{array}{ccc}-1 & 0 & 1 \\
\text { urs control } & \text { Favours }\end{array}$ & \\
\hline
\end{tabular}

Risk of bias legend

(A) Random sequence generation (selection bias)

(B) Allocation concealment (selection bias)

(C) Blinding of participants and personnel (performance bias)

(D) Blinding of outcome assessment (detection bias)

(E) Incomplete outcome data (attrition bias)

(F) Selective reporting (reporting bias)

(G) Other bias

Figure 2 Forest plot of recall or knowledge after information provision interventions.

Boguradzka et al. ${ }^{44}$ reported a significant positive impact of providing medical information with full disclosure of benefits and disadvantages (in the case of Boguradzka et al. ${ }^{44}$ together with structured information) on patients' experienced side effects and participation in screening, respectively. Kim et al. ${ }^{47}$ tested another persuasive strategy for framing an information message: stressing losses and framing the message negatively. The inclusion of three aversive sentences on consequences of smoking led $66.7 \%$ of patients to quit smoking after 6 months compared to the $30.3 \%$ in usual care.

Both Ockene et al. ${ }^{42}$ and Saha and Beach ${ }^{51}$ tested patientcentered communication strategies in the direction of enhancing patient cognitive processing and understanding of the information (e.g., open-ended questions, lay language, demonstrating with visuals and/or gestures). Saha and Beach ${ }^{51}$ also included information provision strategies supporting the physician-patient relationship like expressing empathy, being responsive to the patients' concerns, and personalizing the information to make it relevant to the patient's context. Both studies demonstrated that these interventions improved patients' health-related behaviors, in the direction of reducing alcohol usage ${ }^{42}$ or increasing the analog patients' likelihood of undergoing bypass surgery.

The only study that did not report a clear, positive, and significant improvement in patients' behavioral outcomes (in this case, blood lipid levels, coronary risk, and the frequency of reaching lipid targets) tested the role of repeatedly discussing information on patient's risk for future cardiovascular events showed in a graphical format with a computer printout. $^{46}$ The findings reported were at the border of significance and Grover et al. discussed that choices in the study may have underestimated the intervention arm.

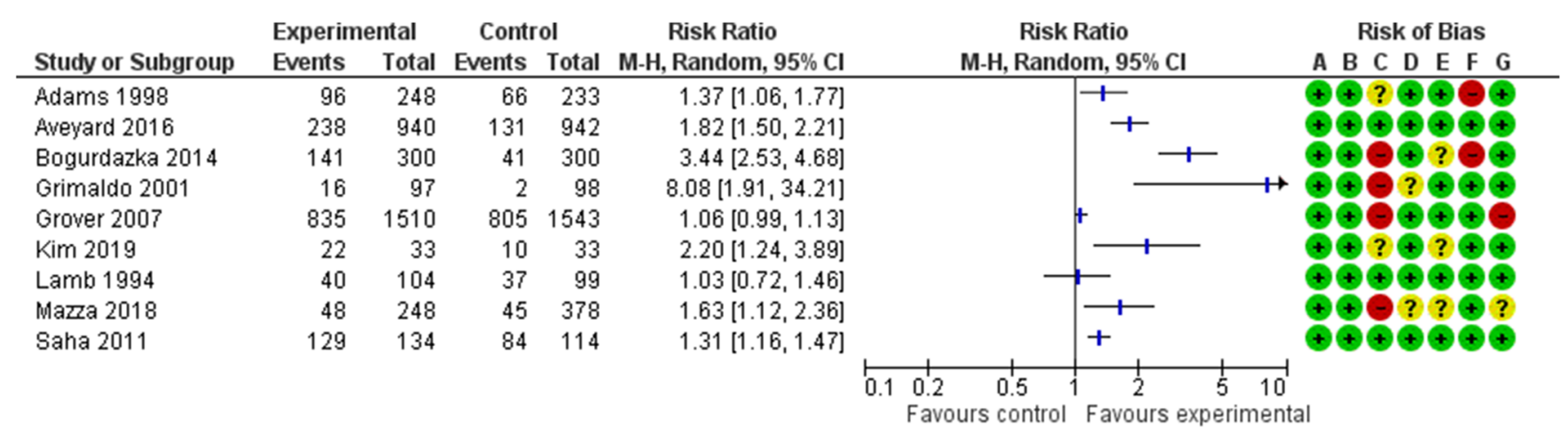

\section{Risk of bias legend}
(A) Random sequence generation (selection bias)
(B) Allocation concealment (selection bias)
(C) Blinding of participants and personnel (performance bias)
(D) Blinding of outcome assessment (detection bias)
(E) Incomplete outcome data (attrition bias)
(F) Selective reporting (reporting bias)
(G) Other bias

Figure 3 Forest plot of behavioral outcomes after information provision interventions. 


\section{DISCUSSION}

To the best of our knowledge, this is the first systematic review investigating the effects of information-giving strategies on patient outcomes across different types of medical settings exclusively including RCTs with low risk of bias. This review of 17 RCTs involving 8256 patients provides strong indications that using deliberate communication strategies when providing information can be more effective in improving patient outcomes than not using deliberate strategies. This main finding enriches results from previous systematic reviews showing how physician communication in general $^{26,28}$ and written or visual information outside the medical consultation can improve patient outcomes. ${ }^{22,23,52,53}$ It sheds light on the particular importance of oral information giving, which is routinely used by physicians in their daily practice and do not require additional resources. If oral information provision is deliberately enhanced by specific strategies to frame the information, this may be a powerful tool for improving important cognitive and behavioral outcomes of patients, as well as many other related outcomes. ${ }^{54}$

Four out of 10 studies testing physicians' information giving strategies on patient information recall reported a positive significant effect. These studies were quite similar in terms of tested strategies, clinical setting, and study design. All but one study testing physicians' information giving strategies on patients' behavioral outcomes reported positive significant effects, also on objectively measured outcomes such as weight or blood lipid levels changes. These studies were very heterogeneous including a wide range of strategies and behavioral outcomes' types, and the findings may have different interpretations and implications.

One possible interpretation involves the extremely different nature of the two considered outcomes and related communication goals (facilitating understanding, changing behaviors), reflected in the use of distinct information framing strategies. In particular, information provision interventions with information recall as outcome mostly tested cognitive aid strategies (like information structuring) in fictitious settings, with the purpose of explaining clinical issues. Some of these studies also tested relationship-oriented strategies (like emotional responsiveness): studies testing relationship-oriented strategies were those showing lowest effects on information recall. One of these studies pointed out the intervening effect of relationship- and trust-related variables on recall ${ }^{38}$, which can potentially explain the reduced impact of this group of studies on recall. The relationship between trust and information recall needs further investigations and may represent a challenge in clinical practice ${ }^{33}$, potentially suggesting a need for physicians to emphasize the importance that patients question their information giving, particularly if patients seem to defer to their authority. On the other hand, for the goal of changing patients' beliefs or behaviors, persuasive strategies generally yielded strong effects. This supports suggestions provided in a JAMA viewpoint on the essential function of persuasion in medical communication. ${ }^{55}$ Information messages aimed at encouraging patients to engage in certain health behaviors may particularly benefit from deliberate embedding within a persuasion frame. While in this systematic review we focus on explicit persuasive information strategies so that patients become engaged in certain beliefs or behaviors, naturalistic studies have also showed that persuasive attempts can be used in subtle, implicit ways by physicians. ${ }^{56}$ Combined, these results call for a discussion about appropriate and deliberate use of persuasion in physician information giving.

Information recall trials were mostly conducted in fictitious settings and tested unique and consistent strategies, while behavior outcome trials were mainly conducted in real-life settings and tested multiple types of strategies. Real-life studies may introduce more variation in the intervening variables and participants. This may produce greater effects on patient outcomes as patients may find the intervention more relevant to them and/or rely more on the physician's advice compared to individuals participating as in the shoes of patients or in fictitious scenarios. Previous research has indicated that analog patients are as reliable as actual patients to evaluate physicians' communication behaviors ${ }^{57,58}$, but this depends on their engagement and by how the scenarios are designed. ${ }^{59}$ Overall, this may indicate the need for a stepwise approach: (1) map behaviors that deserve specific testing, (2) ascertain their potential efficacy in experimental settings, and (3) when variables and mechanisms in play are ascertained, determine how the tested strategy function in real-life settings to produce the desired changes.

Finally, even if the findings reflect information provided for two different communication goals and therefore the strategies used differed substantially, they all have in common the element of information shared by the physician, paired with specific strategies. This may provide some insights about the complex interplay among physicians' information giving, patient information recall, and patient behaviors. The reported effects on behavioral outcomes may be explained by mechanisms that go beyond the information exchange and involve patients' perceptions, knowledge, beliefs, attitudes, and intentions to change. ${ }^{60,61}$ Alternatively, patients may prioritize key items of information to remember, those perceived to enable and motivate certain behaviors. Future studies should explore what information patients prioritize as most important to remember, and also what is the minimum number of recalled items necessary to enable engagement in desired behaviors (e.g., participate in screening programs, lifestyle behavior change). Recently, the "learning by doing" pedagogic approach has been stressed, which considers behaviors as facilitators of learning experiences. ${ }^{62}$ Future studies are needed to understand the dynamics between cognitive and behavioral learning processes as a result of different combinations of information contents and strategies, including possible intervening elements such as patient attitudes, perceptions, beliefs, and knowledge.

\section{Strengths and Limitations}

There are several limitations to this study. First, the extent of positive findings in the included studies may be related to publication biases. Second, findings may need to be interpreted separately for studies assessing recall and behavioral 
outcomes, even if the two outcomes have physicians' information giving as common denominator. Third, we were able to identify only 17 relevant studies to include with rather small samples, despite all being low-risk RCTs.

Strengths include the rigorous, comprehensive search completed in 2020, and resulted in an overview of a largely unexplored key clinical skill. Findings reflect a strict selection of highquality articles based on rigorous screening and quality assessment procedures. The study provides a valuable knowledge base for future studies and practical indications for physicians for successfully conveying information to their patients.

\section{CONCLUSIONS}

Providing medical information using specific framing strategies appears to improve patient information recall or healthrelated behaviors. The study offers insights about specific strategies that physicians can deliberately use to frame medical information to reach defined communication goals and improve patient outcomes. Future studies should test the identified strategies with larger samples, in real-life settings to test cognitive aid strategies for securing patient recall, disentangle the complex interplay between different types of strategies concurrently used to deliver similar messages, and teaching courses on information sharing including framing strategies. Finally, future studies should also investigate on the other part of the puzzle, namely to investigate patients' strategies to make sure physicians understand the information they provide. $^{63}$

Supplementary Information The online version contains supplementary material available at https://doi.org/10.1007/ s11606-021-07044-5.

Acknowledgements: This study within the postdoctoral project "COmmunicating MEdical INFOrmation to patients: An evidencebased toolbox of strategies (COME INFO Project)" was supported by grant 20/11994 from the South-Eastern Norway Regional Health Authority (Helse Sør-Øst).

Corresponding Author: Julia Menichetti, $\mathrm{PhD}$; Health Services Research (HØKH) Centre, Akershus University Hospital, Lørenskog. Norway (e-mail: j.p.m.delor@medisin.uio.no).

Funding Open access funding provided by University of Oslo (incl Oslo University Hospital).

\section{Declarations:}

Conflict of Interest: There are no conflicts of interest to disclose, apart from the funding source (South-Eastern Norway Regional Health Authority; Helse Sør- $\emptyset$ st) that financed the postdoctoral position of the corresponding author and the postdoctoral project that includes this study.

Open Access This article is licensed under a Creative Commons Attribution 4.0 International License, which permits use, sharing, adaptation, distribution and reproduction in any medium or format, as long as you give appropriate credit to the original author(s) and the source, provide a link to the Creative Commons licence, and indicate if changes were made. The images or other third party material in this article are included in the article's Creative Commons licence, unless indicated otherwise in a credit line to the material. If material is not included in the article's Creative Commons licence and your intended use is not permitted by statutory regulation or exceeds the permitted use, you will need to obtain permission directly from the copyright holder. To view a copy of this licence, visit http://creativecommons. org/licenses/by/4.0/.

\section{REFERENCES}

1. Langberg EM, Dyhr L, Davidsen AS. Development of the concept of patient-centredness-A systematic review. Patient Educ Couns 2019;102 (7):1228-1236. https://doi.org/10.1016/j.pec.2019.02.023

2. Richards T, Coulter A, Wicks $\mathbf{P}$. Time to deliver patient centred care. BMJ. 2015;350. https://doi.org/10.1136/bmj.h530

3. Levit L, Balogh E, Nass S, Ganz PA. Patient-centered communication and shared decision making. In Delivering high-quality cancer care: charting a new course for a system in crisis. Washington, DC: National Academies Press; 2013.

4. PRE-MAX Consortium. (2016). Patients' Rights in the European Union Mapping Exercise Final Report. Luxembourg: Publications Office of the European Union. https://ec.europa.eu/health/sites/health/files/cross_border_care/docs/ 2018_mapping_patientsrights_frep_en.pdf. Accessed 10 March 2021.

5. American Hospital Association. Chicago, Catalog no. 157759. 1992. https://www.aapsonline.org/patients/billrts.htm. Accessed 10 March 2021.

6. Matiasek J, Wynia MK. Reconceptualizing the informed consent process at eight innovative hospitals. Jt Comm J Qual Patient Saf 2008;34(3):127-37.

7. Wills CE, Holmes-Rovner M. Patient comprehension of information for shared treatment decision making: state of the art and future directions. Patient Educ Couns 2003;50(3): 285-290.

8. World Health Organization. Regional Office for Europe. Health literacy: the solid facts. https://apps.who.int/iris/handle/10665/326432. 2013 Accessed 10 March 2021.

9. Beauchamp T, Childress J. Principles of biomedical ethics. Oxford, UK: Oxford University Press; 2009.

10. Cornett S. Assessing and Addressing Health Literacy. OJIN. 2009;14(3):2

11. Engel KG, Heisler M, Smith DM, Robinson CH, Forman JH, Ubel PA. Patient comprehension of emergency department care and instructions: are patients aware of when they do not understand? Ann Emerg Med 2009; 53(4): 454-461.

12. Hoek AE, Anker S, van Beeck EF, Burdorf A, Rood P, Haagsma JA Patient Discharge Instructions in the Emergency Department and Their Effects on Comprehension and Recall of Discharge Instructions: A Systematic Review and Meta-analysis. Ann Emerg Med 2020;75(3):435444. https://doi.org/10.1016/j.annemergmed.2019.06.008

13. Kessels R. Patients' memory for medical information. Soc Med. 2003; 96 (5), 219-222. https://doi.org/10.1258/jrsm.96.5.219

14. Horwitz LI, Moriarty JP, Chen C, et al. Quality of Discharge Practices and Patient Understanding at an Academic Medical Center. JAMA Intern Med 2013;173(18):1715-1722. https://doi.org/10.1001/jamainternmed. 2013.9318

15. Sweileh WM, Sa'ed HZ, Nab'a RJA, et al. Influence of patients' disease knowledge and beliefs about medicines on medication adherence: findings from a cross-sectional survey among patients with type 2 diabetes mellitus in Palestine. BMC Public Health 2014; 14:94. https://doi.org/ 10.1186/1471-2458-14-94.

16. Sutcliffe KM, Lewton E, Rosenthal MM. Communication failures: an insidious contributor to medical mishaps. Acad Med 2004; 79(2): 186-194.

17. de Bont EG, Alink M, Falkenberg FC, Dinant GJ, Cals JW. Patient information leaflets to reduce antibiotic use and reconsultation rates in general practice: a systematic review. BMJ Open 2015;5:e007612. https://doi.org/10.1136/bmjopen-2015-007612.

18. Reader TW, Gillespie A, Roberts J. Patient complaints in healthcare systems: a systematic review and coding taxonomy. BMJ Qual Saf 2014;23:678-689. https://doi.org/10.1136/bmjqs-2013-002437

19. Sheard C, Garrud P. Evaluation of generic patient information: effects on health outcomes, knowledge and satisfaction. Patient Educ Couns. 2006; 61:43-7. https://doi.org/10.1016/j.pec.2005.02.004.

20. Husson O, Mols F, Van de Poll-Franse LV. The relation between information provision and health-related quality of life, anxiety and depression among cancer survivors: a systematic review. Ann Oncol. 2010; 22:761-72. https://doi.org/10.1093/annonc/mdq413. 
21. Fox R. Informed choice in screening programmes: do leaflets help? A critical literature review. J Public Health 2006; 28(4): 309-317. https:// doi.org/10.1093/pubmed/fdl066.

22. Cruz-Oliver DM, Rueda AP, Viera-Ortiz L, Washington KT, Oliver DP The Evidence Supporting Educational Videos for Patients and Caregivers Receiving Hospice and Palliative Care: A Systematic Review. Patient Educ Couns 2020;103(9): 1677-1691.

23. Schubbe D, Scalia $\mathbf{P}$, Yen RW, et al. Using pictures to convey health information: A systematic review and meta-analysis of the effects on patient and consumer health behaviors and outcomes. Patient Educ Couns 2020; 103(10): 1935-1960.

24. Menichetti J, Lie HC, Mellblom AV, et al. Tested communication strategies for providing information to patients in medical consultations: A scoping review and quality assessment of the literature. Patient Educ Couns. 2021;20:S0738-3991(21)00046-X. https://doi.org/10.1016/j. pec.2021.01.019.

25. Colledge A, Car J, Donnelly A, Majeed A. Health information for patients: time to look beyond patient information leaflets. J R Soc Med 2008; 101(9): 447-453. https://doi.org/10.1258/jrsm.2008.080149

26. Hall JA, Roter DL, Katz NR. Meta-analysis of correlates of provider behavior in medical encounters. Med Care 1988;26:657-675.

27. Stewart MA. Effective physician-patient communication and health outcomes: a review. CMAJ.1996; 152:1423-1433.

28. Zolnierek KB, Dimatteo MR. Physician communication and patient adherence to treatment: a meta-analysis. Med Care 2009;47(8): 826-834. https://doi.org/10.1097/MLR.0b013e31819a5acc

29. Uitterhoeve RJ, Bensing JM, Grol RP, Demulder PHM, van Achterberg $\mathbf{T}$. The effect of communication skills training on patient outcomes in cancer care: a systematic review of the literature. Eur J Cancer Care 2010;19(4): 442-457.

30. Becker C, Lecheler L, Hochstrasser S, et al. Association of Communication Interventions to Discuss Code Status With Patient Decisions for Do-Not-Resuscitate Orders: A Systematic Review and Meta-analysis. JAMA Netw Open 2019;2(6):e195033. https://doi.org/10.1001/jamanetworkopen.2019.5033

31. Liberati A, Altman DG, Tetzlaff J, et al. The PRISMA statement for reporting systematic reviews and meta-analyses of studies that evaluate healthcare interventions: explanation and elaboration. BMJ. 2009;21;339:b2700. https://doi.org/10.1136/bmj.b2700.

32. Pearson SD, Raeke LH. Patients' trust in physicians: many theories, few measures, and little data. J Gen Intern Med 2000; 15(7): 509-513. https://doi.org/10.1046/j.1525-1497.2000.11002.x

33. Langewitz W. Reaching wise decisions, shared decision making, and information recall-A causal relationship or just an association?. Patient Educ Couns 2020; 103(1):2

34. Ackermann S, Ghanim L, Heierle A, et al. Information structuring improves recall of emergency discharge information: a randomized clinical trial. Psychol Med 2017; 22:646-62. https://doi.org/10.1080/ 13548506.2016.1198816.

35. Bennett DL, Dharia CV, Ferguson KJ, Okon AE. Patient-physician communication: informed consent for imaging-guided spinal injections. J Am Coll Radiol 2009; 6:38-44. https://doi.org/10.1016/j.jacr.2008.08. 004.

36. Danzi OP, Perlini C, Tedeschi F, et al. Affective communication during bad news consultation. Effect on analogue patients' heart rate variability and recall. Patient Educ Couns. 2018; 101:1892-9. https://doi.org/10. 1016/j.pec.2018.06.009.

37. Lehmann V, Labrie NH, van Weert JC, et al. Tailoring the amount of treatment information to cancer patients' and survivors' preferences: effects on patient-reported outcomes. Patient Educ Couns. 2020;103:514-20. https://doi.org/10.1016/j.pec.2019.09.024

38. Lehmann V, Labrie $\mathbf{N}$, van Weert $\mathbf{J}$, et al. Provider caring and structuring treatment information to improve cancer patients' recall: Does it help?. Patient Educ Couns. 2020;103:55-62. https://doi.org/10.1016/j.pec.2019.07.011

39. Visser LN, Tollenaar MS, van Doornen LJ, de Haes HC, Smets EM. Does silence speak louder than words? The impact of oncologists' emotion-oriented communication on analogue patients' information recall and emotional stress. Patient Educ Couns 2019; 102:43-52. https://doi.org/10.1016/j.pec.2018.08.032

40. Werner A, Holderried F, Schäffeler N, et al. Communication training for advanced medical students improves information recall of medical laypersons in simulated informed consent talks-a randomized controlled trial. BMC Med Educ 2013;13:15. https://doi.org/10.1186/1472-6920-13-15.
41. Biglino C, Capelli J, Wray S, et al. 3D-manufactured patient-specific models of congenital heart defects for communication in clinical practice: feasibility and acceptability. BMJ Open 2015;5. https://doi.org/10. 1136/bmjopen-2014-007165.

42. Ockene JK, Adams A, Hurley TG, Wheeler EV, Hebert JR. Brief physician- and nurse practitioner-delivered counseling for high-risk drinkers: does it work? Arch Intern Med 1999; 159(18):2198-205. https://doi.org/10.1001/archinte.159.18.2198.

43. Aveyard P, Lewis A, Tearne S, et al. Screening and brief intervention for obesity in primary care: a parallel, two-arm, randomised trial. Lancet; 2016; 388:2492-500. https://doi.org/10.1016/S0140-6736(16)31893-1.

44. Boguradzka M, Wiszniewski MF, Kaminski E. et al. The effect of primary care physician counseling on participation rate and use of sedation in colonoscopy-based colorectal cancer screening program-a randomized controlled study. Scand J Gastroenterol 2014; 49:878-84. https://doi.org/10.3109/00365521.2014.913191.

45. Grimaldo DA, Wiener-Kronish JP, Jurson T, Shaughnessy TE, Curtis JR, Liu LL. A randomized, controlled trial of advance care planning discussions during preoperative evaluations. Anesthesiology. 2001; 95:43-50. https://doi.org/10.1097/00000542-200107000-00012.

46. Grover SA, Lowensteyn I, Joseph L, et al. Patient knowledge of coronary risk profile improves the effectiveness of dyslipidemia therapy: the CHECK-UP study: a randomized controlled trial. Arch Intern Med 2007;167:2296-303. https://doi.org/10.1001/archinte.167.21.2296.

47. Kim BS, Lim YH, Shin JH, et al. The impact of aversive advice during percutaneous coronary intervention on smoking cessation in patients with acute coronary syndrome. Glob Heart. 2019; 14:253-7. https://doi. org/10.1016/j.gheart.2019.04.001.

48. Lamb GC, Green SS, Heron J. Can physicians warn patients of potential side effects without fear of causing those side effects?. Arch Intern Med 1994;154:2753-6. https://doi.org/10.1001/archinte.1994. 00420230150018

49. Mazza $\mathbf{C J}$, Watson $\mathbf{A}$, Taft $\mathbf{J}$, et al. Increasing long-acting reversible contraceptives: the Australian Contraceptive ChOice pRoject (ACCORd) cluster randomized trial. Am J Obstet Gynecol 2020; 222: S921-e1. https://doi.org/10.1016/j.ajog.2019.11.1267.

50. Colombara F, Martinato M, Girardin G, Gregori D. Higher levels of knowledge reduce health care costs in patients with inflammatory bowel disease. Inflamm Bowel Dis 2015;21:615-22. https://doi.org/10.1097/ MIB.0000000000000304.

51. Saha S, Beach MC. The impact of patient-centered communication on patients' decision making and evaluations of physicians: a randomized study using video vignettes. Patient Educ Couns 2011;84:386-92. https://doi.org/10.1016/j.pec.2011.04.023.

52. Stacey D, Légaré $\mathbf{F}$, Lewis $\mathbf{K}$, et al. Decision aids for people facing health treatment or screening decisions. Cochrane Database Syst Rev 2017;4: CD001431. https://doi.org/10.1002/14651858.CD001431.pub5

53. Krasnoryadtseva A, Dalbeth N, Petrie KJ. The effect of different styles of medical illustration on information comprehension, the perception of educational material and illness beliefs. Patient Educ Couns 2020;103 (3):556-562.

54. Street RL Jr, Makoul G, Arora NK, Epstein RM. How does communication heal? Pathways linking clinician-patient communication to health outcomes. Patient Educ Couns 2009;74(3):295-301. https://doi.org/10. 1016/j.pec.2008.11.015.

55. Shaw D, Elger B. Evidence-Based Persuasion: An Ethical Imperative. JAMA. 2013;309(16):1689-1690. https://doi.org/10.1001/jama.2013.2179

56. Landmark AM, Svennevig J, Gulbrandsen P. Negotiating treatment preferences: Physicians' formulations of patients' stance. Soc Sci Med 2016;149:26-36. https://doi.org/10.1016/j.socscimed.2015.11.035.

57. van Vliet LM, van der Wall E, Albada A, PMM S, Verheul W, Bensing JM. The validity of using analogue patients in practitioner-patient communication research: systematic review and meta-analysis. J Gen Intern Med 2012;27:1529-43.

58. Blanch-Hartigan D, Hall JA, Krupat E, Irish JT. Can naive viewers put themselves in the Patients' shoes? Reliability and validity of the analogue patient methodology. Med Care 2013;51:E16-21.

59. Visser LNC, Bol N, Hillen MA, et al. Studying medical communication with video vignettes: a randomized study on how variations in videovignette introduction format and camera focus influence analogue patients' engagement. BMC Med Res Methodol 2018; 18: 15. https:// doi.org/10.1186/s12874-018-0472-3 
60. Ajzen I. The theory of planned behavior. Organ Behav Hum Decis Process 1991;50(2):179-211.

61. Skinner CS, Tiro J, Champion VL. The Health Belief Model. In Glanz K, Rimer BK, Viswanath KV, eds. Health behavior: Theory, research, and practice. New Jersey, US: Jossey-Bass/Wiley; 2015.

62. Tabak F, Lebron M. Learning by doing in leadership education: experiencing followership and effective leadership communication through role-play. J Lead Educ 2017;16(2):199-212.
63. Street Jr RL. Information giving, managing, and understanding in clinical encounters. Patient Educ Couns 2021; 104:1831-2. https://doi. org/10.1016/j.pec.2021.05.027.

Publisher's Note: Springer Nature remains neutral with regard to jurisdictional claims in published maps and institutional affiliations. 